\title{
Analysis of Conditions Required for a Qualified Football Referee
}

\author{
Jia You \\ College of Physical Education \\ Hubei University of Education \\ Wuhan, China 430205
}

\begin{abstract}
Without football referee, there is no real football match. The football referee is an important part of the football match. In recent years, football matches have been held frequently, and the law enforcement standards of referees are getting higher and higher. Therefore, the football referee shall have good basic qualities in order to ensure the smooth progress of the event. With the quality of literature method, questionnaire and mathematical statistics, the paper analyzes problems of referees in Hubei Football Association, and put forward corresponding countermeasures, providing a powerful guidance for the development of referee.
\end{abstract}

Keywords—referee; football; quality; football match

\section{INTRODUCTION}

Football originated from Chinese Cuju. Even so, Chinese football is unsatisfactory in the world ranking. After the rectification of the last two years, Chinese people's passion for football burn once again. With it, more and more people begin to play football. The demand for football referees is also increasing dramatically.

I have been working as referee for more than a year. I found that there were still many things that the grassroots referees need to learn. Some grassroots referees didn't even know what they were going to study. Therefore, the author has conducted a questionnaire survey on grassroots referees about conditions required for a qualified football referee according to my experience, and put forward some countermeasures, hoping to help the grassroots referees.

\section{RESEARCH OBJECTS AND METHODS}

\section{A. Research Objects}

A total of 60 elementary, national secondary, national first and national football referees registered in Hubei Football Association and Wuhan Football Association.

\section{B. Research Methods}

1) Literature research method: Look up and sort relevant literatures about domestic and foreign professional football referee through databases of China Journal Net, Chinese Master and doctoral thesis, and Wanfang Database, and it provides a theoretical basis for this study.
2) Questionnaire: A questionnaire survey was conducted among 60 football referees of Hubei Football Association and Wuhan Football Association. 60 questionnaires were issued, 60 were recovered, and 58 questionnaires were used. The recovery rate was $97 \%$.

3) Data analysis: Analyze data and make a table for analysis.

\section{RESUltS AND ANALYSIS}

\section{A. Research Results}

1) Survey of the ideological qualities of football referees in Hubei Football Association: Ideological and moral qualities are the internal standards for a referee, which includes professional ethics and law enforcement motivation. Professional ethics is the code of conduct that a referee shall abide by in law enforcement, and is the basic guarantee for football players to compete in the same field and compete in a fair manner. The motivation of law enforcement is a professional quality of referees. It concerns whether a football referee can devote himself to the football referee business with a lofty sense of dedication and a strong sense of responsibility. The following is a survey of the ideological qualities of the football referees in Hubei province. See "Table I".

TABLE I. SURVEY OF THE IDEOLOGICAL QUALITY OF FOOTBALL REFEREES IN HUBEI

\begin{tabular}{|l|l|l|l|l|}
\hline $\begin{array}{c}\text { Content of } \\
\text { ideological qualities }\end{array}$ & Well & Percentage & Not well & Percentage \\
\hline Love football & 58 & $100 \%$ & 0 & $0.0 \%$ \\
\hline $\begin{array}{l}\text { Have good service } \\
\text { awareness }\end{array}$ & 48 & $82.7 \%$ & 10 & $17.2 \%$ \\
\hline Abide by referee rules & 56 & $96.6 \%$ & 2 & $3.4 \%$ \\
\hline $\begin{array}{l}\text { Enforce the law } \\
\text { impartially }\end{array}$ & 50 & $86.2 \%$ & 8 & $13.8 \%$ \\
\hline Obey regulations & 53 & $91.4 \%$ & 5 & $8.6 \%$ \\
\hline
\end{tabular}

From "Table I", it can be seen that football referees in Hubei province have high ideological quality and all love football. But their service consciousness and law enforcement quality are not ideal and need to improve.

2) Survey of psychological qualities of football referees in Hubei: The psychological quality of football referees affects the ability to judge. The referee should keep a sober mind, 
have a quickness of thinking and reaction and a clam emotion, observe appropriately, and have a strong anti-interference ability and psychological endurance. The referee should observe and think, decide resolutely, judge accurately, take full consideration and be quick and have a good attentiveness and proper speed in rule enforcement. In addition, the referee should have a strong achievement motivation, a strong ability against challenges and a awareness of success and confidence, a high self-control ability, indomitable will, an active adaptive ability, a sensitive strain capacity and a good attentiveness. The following is the survey of psychological quality of referees in Hubei Province, as shown in "Table II".

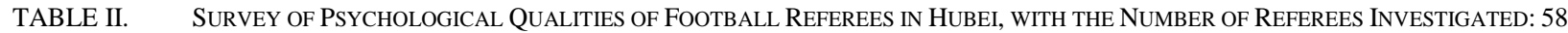

\begin{tabular}{|l|l|l|l|l|}
\hline \multicolumn{1}{|c|}{ Content } & \multicolumn{1}{c|}{ Well } & \multicolumn{1}{c|}{ Percentage } & \multicolumn{1}{c|}{ Not well } & \multicolumn{1}{c|}{ Percentage } \\
\hline Don't have psychological stress & 34 & $58.6 \%$ & 24 & $41.4 \%$ \\
\hline Have a strong achievement motivation & 56 & $96.4 \%$ & 2 & $3.6 \%$ \\
\hline Keep a cool head & 46 & $79.3 \%$ & 22 & $20.7 \%$ \\
\hline Have a quickness of thinking and reaction & 42 & $72.4 \%$ & 16 & $27.6 \%$ \\
\hline Have a good attentiveness & 38 & $65.5 \%$ & 20 & $34.5 \%$ \\
\hline Have a good strain capacity & 28 & $48.3 \%$ & 30 & $51.7 \%$ \\
\hline
\end{tabular}

Through the data of "Table II", it can be seen that the psychological stress in the field has affected all kinds of refereeing abilities. Therefore, it is urgent to improve the psychological quality of the football referees in Hubei province.

3) Survey of physical fitness of football referees in Hubei: With the rapid development of football, the pace and speed of attack and defense transition is accelerated apparently. The frequent physical contacts in the field make covert occupation fouls and diving breed. It requires higher requirements to the physical quality of referees. Only with a good physical quality, can a referee have more positioning, come close to the ball, see clearly and judge accurately. The following is a survey of the physical fitness of the football referees in Hubei, as shown in "Table III" and "Fig. 1".

TABLE III. SURVEY OF PHYSICAL FITNESS OF FOOTBALL REFEREES IN Hubei PROVINCE

\begin{tabular}{|l|l|l|l|}
\hline 12-minute running & Above 3000m & 2500m 3000m & Below 2500m \\
\hline $\begin{array}{l}\text { The number of } \\
\text { referees investigated }\end{array}$ & 16 & 39 & 3 \\
\hline Ratio & $27.6 \%$ & $67.2 \%$ & $5.2 \%$ \\
\hline
\end{tabular}

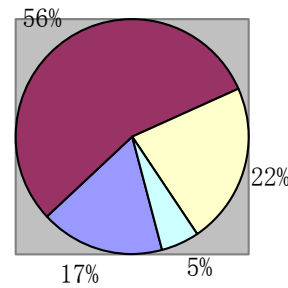

\begin{tabular}{|l|}
$\square 17-19$ \\
$\square 20-22$ \\
$\square 23-25$ \\
$\square$ over 26 \\
\hline
\end{tabular}

Fig. 1. The ages of the referees in Hubei.

From "Table III" and "Fig. 1", we can see that the football referees in Hubei have better physical qualities, and most referees are between the ages of 17 and 25. They are in the best physical condition. But they need regular exercise to maintain a good physical quality.

4) Survey of professional qualities of football referees in Hubei: The professional quality of a football referee is the combination of the theoretical knowledge and executive experience of a football referee, which reflects the refereeing level of a referee on the field, and is an important guarantee for the smooth progress and completion of the competition. The following is a survey of the professional quality of the football referees in Hubei Province, as shown in "Table IV".

TABLE IV. SURVEY OF PROFESSIONAL QUALITY OF FoOTBALL REFEREES IN HUBEI, WITH THE NUMBER OF REFEREES INVESTIGATED: 58

\begin{tabular}{|l|l|l|l|l|}
\hline \multicolumn{1}{|c|}{ Content Percentage } & $\begin{array}{l}\text { Not } \\
\text { well }\end{array}$ & Percentage \\
\hline $\begin{array}{l}\text { Be proficient in the } \\
\text { competition rules }\end{array}$ & 54 & $93.1 \%$ & 4 & $6.9 \%$ \\
\hline $\begin{array}{l}\text { Be proficient in } \\
\text { refereeing law }\end{array}$ & 55 & $94.8 \%$ & 3 & $5.2 \%$ \\
\hline $\begin{array}{l}\text { Know football skills and } \\
\text { tactics }\end{array}$ & 46 & $79.3 \%$ & 12 & $20.7 \%$ \\
\hline $\begin{array}{l}\text { Accurately call a foul or a } \\
\text { improper behavior }\end{array}$ & 40 & $68.9 \%$ & 18 & $31.1 \%$ \\
\hline $\begin{array}{l}\text { Accurately warn or foul } \\
\text { out }\end{array}$ & 55 & $94.8 \%$ & 3 & $5.2 \%$ \\
\hline $\begin{array}{l}\text { Give confident, fair and } \\
\text { clear sign }\end{array}$ & 37 & $63.8 \%$ & 21 & 35.2 \\
\hline $\begin{array}{l}\text { Move or chose position } \\
\text { well }\end{array}$ & 29 & $50.0 \%$ & 29 & $50.0 \%$ \\
\hline $\begin{array}{l}\text { Reasonably use the } \\
\text { diagonal } \\
\text { system }\end{array}$ & 53 & $91.4 \%$ & 5 & $8.6 \%$ \\
\hline $\begin{array}{l}\text { Coordinate with assistant } \\
\text { referee well }\end{array}$ & 31 & $53.4 \%$ & 27 & $46.6 \%$ \\
\hline
\end{tabular}

As can be seen from "Table IV" overall professional qualities of football referees in Hubei are not high. Most of them are blur about skills and tactics, and cannot make accurate decision on foul and improper behavior. They cannot move and chose position well, or coordinate with assistant referee well. So, they need to improve their professional qualities.

The assistant referee's professional qualities include flag showing, running and choosing positioning, and the coordinating with the referee actively. Only when the assistant referee gives accurate, timely and standardized flag signals in the proper position, the referee can give the correct penalty. "Table V" is a survey of assistant referees. 
TABLE V. SURVEY OF THE QUALITY OF ASSISTANT REFEREES, WITH THE NUMBER OF REFEREES INVESTIGATED: 58

\begin{tabular}{|l|l|l|l|l|}
\hline \multicolumn{1}{|c|}{ Content } & Well & Percentage & \multicolumn{1}{|c|}{$\begin{array}{l}\text { Not } \\
\text { well }\end{array}$} & Percentage \\
\hline Complete duties & 58 & $100 \%$ & 0 & $0.0 \%$ \\
\hline $\begin{array}{l}\text { Flag showing: } \\
\text { standard, timely and } \\
\text { normative }\end{array}$ & 36 & $62.1 \%$ & 22 & $37.8 \%$ \\
\hline $\begin{array}{l}\text { Running and } \\
\text { choosing positioning: } \\
\text { running method, } \\
\text { running speed and } \\
\text { positioning }\end{array}$ & 57 & $98.3 \%$ & 1 & $1.7 \%$ \\
\hline $\begin{array}{l}\text { Coordinate actively: } \\
\text { time, substitution, } \\
\text { foul and accident }\end{array}$ & 47 & $81.0 \%$ & 10 & $19 \%$ \\
\hline
\end{tabular}

As can be seen from "Table V", the assistant referees' biggest problem is that the flat showing is not standard and they cannot coordinate well with the referees. It needs assistant referees to be strict with themselves and prepare well before match.

The professional qualities of fourth official include management before, within and after match, taking charge of substitution in match, managing technological field, coordinating the work of referee, and giving evaluation and suggestion on work of referee and assistant referee.

TABLE VI. SURVEY OF THE PROFESSIONAL QUALITIES OF FOURTH OFFICIALS, WITH THE NUMBER OF FOURTH OFFICIAL INVESTIGATED: 58

\begin{tabular}{|l|l|l|l|l|}
\hline \multicolumn{2}{|c|}{ Content Well } & Percentage & $\begin{array}{l}\text { Not } \\
\text { well }\end{array}$ & Percentage \\
\hline $\begin{array}{l}\text { Manage before, } \\
\text { within and after } \\
\text { match }\end{array}$ & 58 & $100.0 \%$ & 0 & $0.0 \%$ \\
\hline $\begin{array}{l}\text { Take charge of } \\
\text { substitution within } \\
\text { match }\end{array}$ & 58 & $100.0 \%$ & 0 & $0.0 \%$ \\
\hline $\begin{array}{l}\text { Management on } \\
\text { technological field }\end{array}$ & 50 & $86.2 \%$ & 8 & $13.8 \%$ \\
\hline $\begin{array}{l}\text { Coordinate the work } \\
\text { of referee }\end{array}$ & 58 & $100.0 \%$ & 0 & $0.0 \%$ \\
\hline $\begin{array}{l}\text { Give evaluation and } \\
\text { suggestion on work } \\
\text { of referee and } \\
\text { assistant referee }\end{array}$ & 3 & $5.2 \%$ & 55 & $94.8 \%$ \\
\hline
\end{tabular}

It can be seen from "Table VI" fourth officials in the match can do well in their duties. But they didn't give suggestions to the work of referee and assistant referee. It is one major factor why the professional qualities of some referees are not well.

5) Survey of professional theoretical level of football referees in Hubei: If you want to be a good referee, you shall have a good theory knowledge of football, be familiar with and master the professional theory knowledge of refereeing: (1) standard size of football field; (2) the football rules and the refereeing law; (3) standard blowing, judgment and punishment; (4) the running route of referee, gesture, flag showing; (5) the division of referee and assistant referee; (6) the arrangement method of football match.
TABLE VII. SURVEY OF PROFESSIONAL ThEORY OF FoOTBALL REFEREES IN HUBEI PROVINCE

\begin{tabular}{|l|l|l|l|}
\hline \multicolumn{1}{|c|}{$\begin{array}{c}\text { Master the theory knowledge of } \\
\text { football well }\end{array}$} & Well & Better & Not well \\
\hline $\begin{array}{l}\text { The number of referee investigated: } \\
58\end{array}$ & 56 & 2 & 0 \\
\hline Percentage & $\begin{array}{l}96.6 \\
\%\end{array}$ & $3.4 \%$ & $0 \%$ \\
\hline
\end{tabular}

From "Table VII" it can be seen that professional theory level of Hubei football referees are very good. But they also have room for improvement. Every referee shall be familiar with the basic theoretical knowledge of football.

6) Basic skills of football referees in Hubei: Whistling, gesturing, flag showing, running method and movement route are the basic skills of referee. It can show the attitude and level of referee towards work. So, the basic skills of referee are important for a good referee.

TABLE VIII. SURVEY OF BASIC SKILls OF FOOTBALl REFEREES IN HubEI, WITH THE NUMBER OF REFEREE INVESTIGATED: 58

\begin{tabular}{|l|l|l|l|l|}
\hline \multicolumn{1}{|c|}{ Content } & Well & Percentage & \multicolumn{1}{|c|}{$\begin{array}{c}\text { Not } \\
\text { well }\end{array}$} & Percentage \\
\hline Whistling & 36 & $62.1 \%$ & 22 & $37.9 \%$ \\
\hline Gesturing & 43 & $74.1 \%$ & 15 & 25.9 \\
\hline Flag showing & 42 & $72.4 \%$ & 16 & $27.6 \%$ \\
\hline Proper running method & 48 & $82.8 \%$ & 10 & 17.2 \\
\hline Proper movement route & 57 & 98.3 & 1 & $1.7 \%$ \\
\hline
\end{tabular}

From the data of "Table VIII", we can see that the basic skills of the football referees in Hubei can be greatly improved, and the referees need to constantly improve themselves.

\section{B. Countermeasures}

1) Training of football referee's ideological quality: The football referee's moral quality mainly includes ideological morality and professional ethics. The core of professional ethics is "seriousness, earnest, impartiality and accuracy", which is the moral rules and norms that an referee shall observe. The referees should reflect on themselves, conduct ideological and moral education for self, correct the motivation of the refereeing, and cultivate sincere feelings about the cause of the referee.

2) Training of psychological quality of football referees: Football referees should pay great attention to their psychological qualities and make adequate preparations for possible conflicts in the event of sanctions. Keep clear head, calm down, analyze changes on the field, make accurate judgments about events and deal with them properly. Finally, referees should strengthen the study of rules and the accumulation of practical experience, so as to make our decisions more accurate. To give accurate penalty can improve a referee's self-confidence, and psychological quality will increase with the improvement of self-confidence.

3) Training of physical fitness of football referees: The main forces of the football referees are students majoring in Physical Education in colleges and universities, and their physical fitness is generally better. But the physical quality is like sailing against the current, so the referees shall keep 
exercising. To have a good physical quality can ensure a farther career of referee.

4) Training of professional quality of football referees: Reasonable penalty ability and accurate recognition ability are crucial to referee, mainly including the proper use of rules, correct refereeing in the law enforcement process, appropriate use of rules, the rational use of the favorable terms and the good control of the game scene. In the process of law enforcement and penalty, the application of rules shall be flexible, do not violate the rules, and players can accept. All this need referee to solve it flexibly under the premise of fairness.

5) Training of football referee's professional theoretical level: Good theory knowledge of football is the premise of a good referee, and the theoretical knowledge directly affects the penalty of on-the-spot sanctions. The most typical is the penalty of direct free kick and indirect free kick. Outside the field, referees need to strengthen their theoretical knowledge, so that they can grow faster in their careers.

6) Training of basic skills of football referees: Basic skills of referees on the field include whistling, gesturing, flag showing and movement route. If a referee gives a nonstandard whistling, gesturing or flag showing when refereeing on the field, it will mistake other referees and they cannot communicate clearly. As a result, the game will be not smooth and players' emotions will be affected. Therefore, the referee shall strengthen the theoretical study. They can practice before mirror, point out nonstandard gestures and correct to improve themselves.

\section{CONCLUSION}

Through the survey of football referees in Hubei, it can be found that most of these referees have good physical and ideological qualities. But their psychological quality and professional quality is not satisfactory, which is one reason why Hubei referees have poor professional quality. So, they need to improve their psychological quality and professional quality at the present stage. Referees should see matches, exchange and practice frequently. We should be good at summing up, set up correct goals and study hard in our work. We should find deficiencies, draw lessons from others, explore ways to solve the problem. We should learn to reflect and analyze all kinds of situations in match. We should learn to speak artfully, come down to earth and pay attention to the occasion, express in order, and use the jargon as much as possible. Referees shall try our best to referee in matches at all levels, accumulate experience in practice, grasp the ability to deal with accidents. Referees also should learn to play football. Play more, and it can not enhance the physical quality, but also can improve referee's refereeing ability and help make preventive decisions.

\section{REFERENCES}

[1] Wei Yingli, Ma Xingming. Refereeing Problems of Heilongjiang Football Referees and Countermeasures. Journal of Harbin Institute Of Physical Education, 2006, 24 (1): 104-105.
[2] Xie Gengfang. Quality and Ability of Football Referees. Journal of Zhaoqing University, 2003 (02)

[3] Xie Gengfang. Practice Study of Training Football Referees in College Physical Education. Journal of Zhaoqing University, 2002, 23 (5): 44 45

[4] Liu Jie: Ways to Improve the Ability of On-the-spot Enforcement of Football Referees; Symposium on Teaching and Research of Electronic Information Specialty in Higher Vocational Education in 2011, 2011.

[5] Li Youguan. Flexible Law Enforcement on Different Teams. Collina's Opinion on World Cup Referees. Football Club, July 2010.

[6] Ou Zhou, Wang Endong. Training of Student Football Referees in Colleges and Universities. Journal of Zhuzhou Institute of Technology, 2004, 18 (3): 133-134.

[7] Wan Zha. How to Correctly Use the Red and Yellow Cards in Football Match. Tibet Sports, Feb. 2008. 